\title{
EL MAL EN SANTO TOMÁS DE AQUINO Y EL PROBLEMA DE LA RESPONSABILIDAD HUMANA
}

\section{Dr. Michael Mayne-Nicholls Klenner ${ }^{1}$}

\begin{abstract}
RESUMEN

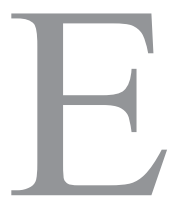

N EL PRESENTE ARTíCULO SE ESTUdia LA CONCEPCiÓN DEL MAL DE SAnto Tomás de Aquino, tarea abordada a partir de la identificación de los principios metafísicos sobre los que se sustenta, en orden a determinar el marco filosófico en el que se integra. Se reconoce en su especulación sobre la causa del mal moral de culpa aquel elemento de su doctrina que puede ser relacionado con el que es uno de los temas centrales de la reflexión contemporánea sobre el mal, a saber, el problema de la responsabilidad humana ante el mal, lo que permite proponer su pensamiento como un posible aporte a esta discusión.
\end{abstract}

Palabras clave: Mal, privación, metafísica creacionista, culpa, responsabilidad.

\section{THE EVIL IN SAINT THOMAS AQUINAS AND THE PROBLEM OF HUMAN RESPONSIBILITY}

\begin{abstract}
In this article the conception of evil of Saint Thomas Aquinas is studied, a task approached from the identification of the metaphysical principles on which it is sustained, in order to determine the philosophical framework in which it is integrated. It is recognized in his speculation about the cause of the moral evil of guilt that element of his doctrine that can be related to what is one of the central themes of contemporary reflection on evil, namely, the problem of human responsibility to evil, which allows to propose his thought as a possible contribution to this discussion.
\end{abstract}

Keywords: Evil, privation, creationist metaphysics, guilt, responsibility.

1 Escuela Naval Arturo Prat, Valparaíso, Chile. Correo maynenicholls@gmail.com 


\section{INTROduCCIÓN}

No es sino la omnipresencia del mal en la existencia humana la principal razón de que esta sea una noción que no ha dejado de estar presente, si bien algunas veces con mayor intensidad que otras, en el devenir del pensamiento filosófico occidental. Desde los inicios de la labor filosófica en Grecia - con Epicuro formulando una de las primeras y más conocidas enunciaciones sobre el llamado problema del mal-, el esfuerzo por integrar la maldad, en sus múltiples formas, dentro de la vida humana ha sido un constante propósito.

Esta habitual concurrencia del mal como objeto especulativo de la filosofía se ha mantenido hasta hoy. Incluso, lejos de disminuir, ha ido aumentando con el paso del tiempo. Susan Neiman, en su obra El mal en el pensamiento moderno. Una historia no convencional de la filosofía (Neiman 2012), señala que la cuestión del mal llegó a constituirse en uno de los temas centrales de la reflexión filosófica de los siglos XVIII y XIX — para algunos, quizás fue el tema filosófico (Castro 2016, 237-253)—. La modernidad, desde una diversidad de aproximaciones — pictóricas, poéticas, novelescas, filosóficas, entre otras-, se enfrentó decididamente a este problema, principalmente con la maldad que surge desde el propio hombre.

Ahora bien, pese a la fuerte presencia de esta cuestión en los dos siglos precedentes, fue en el siglo XX que la especulación sobre el mal experimentó un impulso nunca antes visto. ¿A qué se debió dicho estímulo? Este se explica por la profunda malignidad a la que el hombre se vio enfrentado (Possenti 1997, 9; Haag 1981, 213; Delbanco, 19972) en algún punto se produjo un quiebre a partir de algo que no parecía ser similar a las múltiples expresiones de mal conocidas e "incorporadas" por la

2 "Si existe una herencia del siglo XX, acaso el más oscuro y sangriento de la historia humana, no puede ser otra que la inquietante pregunta sobre el mal. El pensamiento antiguo inició una gigantomaquia en torno al ser y al devenir, cuyo desarrollo dura todavía; en nuestro tiempo, a su vez, se anuncia una gigantomaquia en torno al mal". Pese a todas las aberraciones e injusticias cometidas, y pese a todo el dolor y sufrimiento padecido por el hombre durante su historia, se suele decir que fue recién en el siglo XX que el hombre realmente se enfrentó cara a cara con el mal. Herbert Haag, teólogo católico suizo, en su obra El problema del mal, de 1978, afirma que "vivimos una escalada del mal, así lo parece, como nunca se había dado en la historia de la humanidad". Andrew Delbanco, 17 años después, en La muerte de Satán, asegura que "vivimos el siglo más brutal de nuestra historia". Lo experimentado fue tal, que ha habido bastante acuerdo en llamarle "el siglo del mal". 
conciencia humana. Quizás con “quiebre” se esté utilizando una expresión que no da el ancho. En algún momento de este siglo se abrió un abismo que separó este algo de todo lo anteriormente visto.

Pero, ¿en qué consiste ese "algo"? Si bien no es solo un único hecho, lugar, ni ser humano el que se encuentra involucrado, este puede ser reducido, siguiendo el camino trazado por autores como Hannah Arendt, Hans Jonas, Emmanuel Levinas y Theodor Adorno, a una sola palabra: Auschwitz (Levinas 1993, 113-126; 12233). Lo ocurrido en aquel campo de concentración/exterminio nazi es la representación exacta de dicho punto de quiebre.

Siguiendo la reflexión que Hannah Arendt hizo sobre estos hechos, es en lugares como Auschwitz donde se dio el mal en su máxima expresión. Aquello la filósofa alemana lo denominó como mal radical, que consiste en una nueva forma de terror, aquel terror total que los Estados totalitarios fueron capaces de aplicar en sus campos de concentración/exterminio, en pos de conseguir la tan ansiada dominación tota (Bernstein 2004, 3234) No fue sino en el contexto de estos elaborados sistemas de terror impuestos por los totalitarismos donde tuvo lugar lo que ha llegado a considerarse el paradigma del mal del siglo XX (Arendt 2014, 74; Bernstein 2015, 155; Arendt 2006, 617-6405)

3 En este sentido, Levinas, en su ensayo "El sufrimiento inútil", afirma: "Creo que todos los muertos del gulag y de todos los demás lugares de tortura de nuestro siglo político están presentes cada vez que se habla de Auschwitz".

4 Como bien apunta Richard Bernstein en su lectura de Arendt, la expresión "mal radical" se utiliza para designar "lo peculiar del mal de la dominación total".

5 Tal como se desprende de su obra Los orígenes del totalitarismo, para Hannah Arendt lo esencial de un régimen totalitario es, precisamente, este uso del terror por parte de la ideología gobernante. Esto explica que uno de los motivos que empujó su pensamiento político y que, a su vez, se volvió uno de los ejes centrales de su investigación corresponda al terror totalitario, una nueva forma de terror de la que Arendt, principalmente a causa de sus orígenes familiares, tenía perfecta conciencia, pero que, cabe señalar, no experimentó en carne propia - aunque estuvo muy cerca de hacerlo, salvándose solo gracias a su escape del campo de detención en Gurs, Francia, antes de ser enviada, con mucha probabilidad, a un encierro y muerte en Auschwitz-. Más aún, en Arendt, la relación entre totalitarismo y terror es incluso más profunda, ya que este último no es una mera característica de los totalitarismos, ni tampoco solo un medio utilizado. Como se puede reconocer en su obra Sobre la violencia, de 1969, cuando Arendt habla de "terror" se refiere a una forma de gobierno: "El terror no es lo mismo que la violencia; es, más bien, la forma de gobierno que llega a existir cuando la violencia, tras haber destruido todo poder, no abdica, sino que, por el contrario, sigue ejerciendo un completo control". El terror como forma de gobierno no es sino el totalitarismo. Por ello, como bien reconoce Richard Bernstein en su reciente obra Violencia. 
Lo significativo del acontecimiento histórico aludido, es que no solo tuvo las esperables consecuencias históricas, políticas y sociales, sino que también tuvo profundos efectos en el pensamiento porvenir. Fue esta extrema experiencia de mal -más que ninguna de las otras, también intensas, que tuvieron lugar en el pasado siglo- la que forzó al hombre a re-pensar lo malo. La filosofía, que no quedó indiferente a tal requerimiento, logró desarrollar una reflexión que, por sus innegables méritos especulativos, extendió su influencia hasta la actualidad, instalando algunos temas como ineludibles, entre los que destacan el problema del sufrimiento y el de la $\mathrm{Fe}$ en Dios. Ahora bien, debido a la relevancia alcanzada, en el presente estudio se abordará aquel que se constituye en el tercer tema fundamental: el problema de la responsabilidad humana ante el mal. Es la deuda que cada hombre tiene a causa de aquella cantidad de mal con la que contribuye a la suma total de maldad existente en el mundo, la problemática que ha exigido los mayores esfuerzos por parte de esta reacción filosófica ante lo sucedido.

Es esta una reflexión que se caracteriza, en primer término, por abordar la cuestión del mal desde un sentido eminentemente moral. El verdadero problema es aquel mal cometido por el hombre, y lo es, entre otros motivos, en cuanto termina, de una manera u otra, redundando en el sufrimiento de otro, o de otra cosa, como lo es el mismo planeta Tierra. A su vez, por manifestar, implícita o explícitamente, una profunda crítica a las teorías precedentes sobre el mal, especialmente respecto al tema destacado, el de la responsabilidad humana. Es repetida la invitación a superar lo hecho en el pasado en pos de abordar adecuadamente los desafíos del presente. Lo vivido hace que lo pensado ya no sea suficiente.

De aquí surge una inquietud. Dentro de estas teorías precedentes se ubica una en especial, que ha sido, por mucho, la de mayor influjo al respecto: la teoría del mal como privatio. Esta doctrina, que encuentra sus primeros desarrollos importantes en

Pensar sin barandillas (2013), Arendt entiende el terror de una manera bastante diferente de la forma en que hoy en día se utiliza dicho término, es decir, en relación con el "terrorismo". Un detalle no menor es que la primera edición de Los origenes del totalitarismo, la de 1951, no contaba con el capítulo titulado Ideología y Terror: de una nueva forma de gobierno, que fue agregado recién en su edición de 1958, siete años después, como tema de cierre para la obra. Este hecho, resultado de una revisión y profundización de sus postulados entre ambas ediciones, es una clara muestra de la importancia que para Arendt tiene el terror en cuanto aspecto definitorio de todo régimen totalitario. 
Plotino y San Agustín, y que contó con su más valiosa sistematización en santo Tomás de Aquino, dominó gran parte de la historia de la Filosofía, y que, si bien ahora cuenta con un peso muy disminuido debido al descrédito provocado por las fuertes críticas a las que ha sido sometida, ha logrado mantener su presencia hasta hoy.

Considerando las exigencias y desafíos propios de la reflexión actual sobre el mal, cabe preguntarse si la doctrina de santo Tomás ha perdido su vigencia. Sin lugar a dudas, el principal factor que atenta contra dicha vigencia, a los ojos de la contemporaneidad, es la naturaleza misma de esta especulación: en el aquinate, la cuestión del mal debe entenderse como un problema fundamentalmente metafísico. Más aún, la filosofía del ser tomista se enmarca en un ámbito mayor, como lo es el de la Creación. Esto, sin embargo, ¿la inhabilita para participar de una discusión como la que se ha venido desarrollando "post-Auschwitz"?

La pregunta que se intentará responder en el presente artículo, es: ¿una visión del mal que encuentra su sustento en una metafísica creacionista, puede aportar a la reflexión contemporánea sobre el problema que nos convoca, es decir, el de la responsabilidad humana? Planteada de otra manera: ¿hay algún elemento propiamente filosófico de su pensamiento que permita identificar en su doctrina sobre el mal aspectos propios de una ética de la responsabilidad?

\section{Algunas consideraciones sobre el problema de la res- PONSABILIDAD HUMANA ANTE EL MAL}

Sobre este tema se encuentra una primera reflexión "post-Auschwitz" en Karl Jaspers, quien, a partir del invierno de 1945-1946, es decir, recién terminada la Segunda Guerra Mundial, y empujado por los hechos ahí ocurridos, se hace cargo del problema de la culpabilidad alemana. ${ }^{6}$ Como resultado de esta reflexión publica, en 1946,

6 Un dato que es decisivo para una mejor comprensión de este autor y de su relación con estos hechos, es que su fusilamiento estaba previsto para el 11 de abril de 1945, pero este no alcanzó a realizarse ya que solo 9 días antes, el 2 de dicho mes, la ciudad de Heidelberg fue liberada por las tropas estadounidenses. 
su obra El problema de la culpa. Sobre la responsabilidad política de Alemania, ${ }^{7}$ en la que afirma su tesis de que, respecto al mal radical cometido por los totalitarismos, hay una culpa metafísica (Jaspers 1998, 53-548) en todos aquellos que no hicieron nada para combatirlos — como ciertas democracias occidentales-, que prefirieron no involucrarse o, peor aún, que fueron indiferentes a tales hechos. Para entender este profundo sentido de culpabilidad, se debe comenzar de la base de que, para Jaspers, todos los hombres que conforman la llamada humanidad se encuentran unidos por lazos invisibles, por un sentido de solidaridad recíproco, y que no es esta una forma de solidaridad cualquiera, sino una llevada a la máxima expresión: cuando un hecho malvado ocurre en el mundo, cada uno es, de alguna manera, en mayor o menor medida, culpable de este. Esta culpabilidad, entonces, consiste en una forma colectiva de responsabilidad de la que nadie puede excluirse. Esto explica su categórica posición: el desastre ocurrido entre los años 1939 y 1945 es el precio a pagar por la no-violencia de 1933 (Ricoeur 2013, 155; Bernstein 2004, 2419).

Se puede advertir que este sentido de responsabilidad ante el mal radical se acerca a lo planteado por Emmanuel Levinas, sintetizado en su exigente - y, para algunos como Richard Bernstein, exagerado (Idem) - principio de que "la justificación del dolor del prójimo es ciertamente el origen de toda inmoralidad (Levinas 1993, 123)". Para el filósofo lituano, la única respuesta que puede ser considerada como proporcionada a este mal que, en cuanto es esencialmente un exceso, no puede ser completamente integrado ni comprendido - lo que este autor denomina la trascendencia del mal-, es la respuesta ética, que consiste en esta responsabilidad infinita por y para el otro, en una relación con este que es profundamente asimétrica, no-recíproca: éticamente hablando, el sufrimiento del otro es más importante que el mío.

7 Bajo el nombre Die Schuldfrage.

8 Cabe aclarar que en El problema de la culpa. Sobre la responsabilidad política de Alemania, Jaspers sugiere que hay distintos tipos de culpabilidad -y sus consiguientes responsabilidades- en el hombre, los que ubica en dos grandes grupos, las culpas individuales y las colectivas. Estas, a su vez, se dividen en cuatro tipos o niveles: la culpa criminal, la culpa política, la culpa moral y la culpa metafísica.

9 En la misma línea, Richard Bernstein reconoce que, ante la maldad radical del siglo XX, el análisis de lo sucedido debe dejar de enfocarse solo en lo cometido por los ejecutores y lo sufrido por las víctimas; este debe dirigirse también hacia los "espectadores", hacia todos aquellos individuos que, si bien no tuvieron responsabilidad directa en los hechos, se mantuvieron vergonzosamente impasibles, sin sentirse responsables del profundo sufrimiento que padecían sus prójimos. 
Otra de las reflexiones destacadas sobre la responsabilidad fue la de Hans Jonas. El "evento Auschwitz" produjo una profunda crisis existencial y doctrinal en este autor, especialmente en lo que respecta a su relación con Dios. Como una respuesta especulativa a este profundo mal, en su ensayo "El concepto de Dios después de Auschwitz. Una voz judía", construye un nuevo y original mito sobre los orígenes y la entrada del mal en el mundo (Jonas 1998, 195-212; 198; Dosse 2013,156 ${ }^{10}$ ), en el que propone la idea de un Dios "que durante un tiempo - el tiempo del proceso universal en progreso - renunció a todo su poder de inmiscuirse en el curso de las cosas del mundo" (Jonas 1998, 209). Jonas rompe con el esquema teológico clásico que muestra al hombre, en cuanto criatura, menesteroso frente a Dios, necesitado de la ayuda de su Creador. En esta relación Creador-criatura ya no es Dios quien cuida al hombre, sino que, al contrario, es el hombre quien tiene a su cargo a Dios (Ibidem, 211 ${ }^{11}$ ).

Esta inversión de los papeles implica el hecho de que es el hombre el único responsable del mal en el mundo. Ya no se puede acusar a Dios de nada, ni puede pedírsele auxilio: este Dios, profundamente dependiente de sus criaturas, no podía hacer mucho para socorrer al hombre ante el mal del siglo XX - mucho menos, en lugares como Auschwitz-. Su limitado poder le dejó desvalido, obligándole a un sufriente silencio. De esta manera, la pregunta que realmente importa no es "¿dónde estuvo Dios en Auschwitz?”, sino, más bien, “¿dónde estuvo el hombre en Auschwitz?”: "No necesitamos ningún dualismo maniqueo para la explicación del mal; este solo surge en los corazones humanos y gana poder en el mundo. En la mera admisión de

10 Sin embargo, según aclara el mismo Jonas, dicho mito ya había sido presentado en un artículo anterior, en el que reflexionaba sobre la inmortalidad, titulado "Zwischen Nichts und Ewigkeit". Debido a su extensión no será transcrito íntegramente aquí, pero la idea central detrás del texto fue adecuadamente sintetizada por François Dosse en Paul Ricoeur: los sentidos de una vida (1913-2005): “[Jonas] Ubica el origen del mal antes de la falta del hombre. El acto creador lleva en germen el peligro del mal en la medida en que la fuente del Ser, la divinidad, ha querido apartarse, retirarse, para que el mundo sea un tiempo y un espacio inmanente liberado de su injerencia. La Creación ya no comienza por una revelación, sino, por el contrario, por un ocultamiento, un retiro, un apartamiento de la divinidad".

11 "Renunciando a su propia invulnerabilidad, el eterno fondo del mundo permitió a este que existiera. Todas las creaturas deben su existencia a esta autonegación y recibieron gracias a ella todo lo que había por recibir del más allá. Una vez que se ha entregado por completo al mundo y a su devenir, Dios ya no tiene nada que dar. Ahora le toca al ser humano darle lo suyo a Dios. Y lo puede hacer procurando, en los caminos de su vida, que no se convierta en motivo para que Dios se arrepienta de haber permitido el devenir del mundo". 
la libertad humana se halla implícita una renuncia al poder divino" (Ibidem, p.209; Dosse 2013, 156 $6^{12}$ )

Otro acontecimiento que influyó en la especulación de Jonas fue el ataque atómico lanzado por Estados Unidos sobre las ciudades japonesas de Hiroshima y Nagasaki, los días 6 y 9 de agosto de 1945, respectivamente, en el marco de la Segunda Guerra Mundial. La devastación y las miles de muertes producidas se constituyeron en un prístino ejemplo del desenfrenado avance de la techne humana, la que ha llegado a entregarle a su creador un poder casi ilimitado. Pero también dejó en evidencia lo tremendamente vulnerable que es la naturaleza ante dicho poder: es una posibilidad latente y perfectamente real que el hombre y su técnica acaben destruyendo el medioambiente, $\mathrm{y}$, con ello, su misma existencia en la Tierra.

\section{En su obra El principio de responsabilidad. Ensayo de una ética para la civilización} tecnológica, de 1979, afirma que la técnica moderna "ha introducido acciones de magnitud tan diferente, con objetos y consecuencias tan novedosos, que el marco de la ética anterior no puede ya abarcarlos" (Jonas 2008, 32). El carácter de la acción humana había cambiado, expandiendo sus límites como nunca antes, (Ibidem, 33 $3^{13}$ ) lo que significó que también se hayan extendido las barreras de su responsabilidad. Ante este nuevo escenario, Jonas comprendió que las fronteras de las teorías éticas precedentes debían ser modificadas (Ibidem, 34). Se hizo necesaria una nueva ética, una que abarque esta nueva dimensión; se requiere, precisamente, una "ética de la responsabilidad" (Ibidem, 40; Bernstein 2004, 268 ${ }^{14}$ ).

12 Esta renuncia trae graves consecuencias para la vida del hombre: como bien reconoce Dosse, es esta autoprivación de intervenir por parte de la divinidad lo que hace tan peligroso al mal.

13 Se puede observar, por ejemplo, una disminución de las limitaciones espaciales y temporales, a cambio de un ensanchamiento espacial y una dilatación temporal. Respecto a sus efectos, se encuentran los caracteres de irreversibilidad y concentración, además de ser acumulativos.

14 En este contexto, Jonas presenta dos sentidos para la responsabilidad: la formal, que consiste en el hecho de que un agente sea responsable e imputable de los propios actos -correspondiendo al sentido clásico de responsabilidad-, y la sustantiva, aquella que tiene todo aquel que actúa por los objetos particulares, como es el caso de la naturaleza. Se puede entender mejor esta segunda forma de responsabilidad a través de la relación padre e hijo, en la que el primero tiene el deber de cuidar por el segundo, de actuar procurando su bienestar, sin que necesariamente se dé el mismo cuidado en sentido inverso -de lo que se puede deducir que, tal como lo planteado por Levinas, la relación de responsabilidad sustantiva también es "no-recíproca"-. Con este objetivo en mente, propone un imperativo categórico para regir las condiciones actuales de la vida y el actuar humano. Siguiendo el modelo kantiano -"obra de tal modo que puedas 
Es necesario reconocer, por último, el aporte que a la discusión sobre este tema hizo Paul Ricoeur, quien, desde mediados del siglo XX hasta principios del siglo XXI, desarrolló una de las más destacadas reflexiones sobre la cuestión del mal (Ricoeur 2008, 171; Ricoeur 2004, 461 ${ }^{15}$ ). Este filósofo francés es uno de los autores que, al igual que Jonas, explícitamente invita a tomar un camino distinto al recorrido en el pasado, con el fin de superar las limitaciones de la reflexión anterior. Tal como se aprecia en una de sus últimas obras, El mal. Un desafío a la filosofía y a la teología, de 2004, esta mirada crítica se sustenta en su consideración de que lo ya pensado sobre el mal no logró dar las respuestas exigidas por un problema de esta profundidad.

Si bien son variadas las críticas que formula a las teorías precedentes, una de las principales es la incapacidad de hacerse responsable ante el mal, especialmente ante el sufrimiento del hombre. Destaca, para este caso en específico, al justo sufriente, aquel individuo que padece el mal sin merecerlo, sin tener culpabilidad moral alguna. Refiriéndose, como ejemplo paradigmático, a las desventuras bíblicas de Job, demuestra la deficiencia de la que adolecen las reflexiones anteriores a la hora de explicar por qué sufren los inocentes. No fue el mito (Ricoeur 2008, 175), ni la teoría de la retribución (Ibidem, 176), no fue San Agustín ni Pelagio (Ibidem, 178),

querer también que tu máxima se convierta en ley universal"-, enuncia su imperativo como "obra de tal modo que los efectos de tu acción sean compatibles con la permanencia de una vida humana auténtica en la Tierra". También puede ser enunciado de otras tres maneras: negativamente, como "obra de tal modo que los efectos de tu acción no sean destructivos para la futura posibilidad de esa vida"; o, reformulando este último, como "no pongas en peligro las condiciones de la continuidad indefinida de la humanidad en la Tierra"; finalmente, considerando esta última enunciación, ahora de manera positiva, como "incluye en tu elección presente, como objeto también de tu querer, la futura integridad del hombre". La idea central que constituye este mandato jonasiano es que el hombre actual debe procurar que, con sus acciones, no esté atentando contra el devenir de los futuros hombres. La invitación de este autor, entonces, es a ser responsables de aquellos seres que también lo son: hay un deber colectivo de preservar a todos los portadores potenciales de dicha responsabilidad. Como acertadamente reconoce Bernstein, dado que esta nueva responsabilidad no tiene límites, bien podría haber dicho Jonas -cosa que explícitamente no hace-, a la manera de Levinas, que se trata de una "responsabilidad infinita".

15 Una de las razones que explica su importancia es lo novedoso de su aproximación. Ricoeur invita a pensar "más" y "de otra manera” este enigma que desafía, como ningún otro, a la audacia filosófica. ¿Cómo? Es a través del lenguaje simbólico que el pensador puede representar la experiencia del mal: su propuesta consiste en una hermenéutica de los símbolos del mal. Enfrentar simbólicamente esta cuestión se justifica, citando una famosa expresión de Ricoeur, porque el símbolo da que pensar: "los grandes símbolos sobre la naturaleza y origen del mal no son unos símbolos más entre otros, sino símbolos privilegiados (...) Todos los símbolos nos hacen pensar, pero estos nos hacen ver de manera ejemplar que en los mitos y en los símbolos hay siempre más que en toda nuestra filosofía". Si a esto se suma el hecho de que los símbolos siempre han formado parte de la cultura humana, como también la inagotabilidad de sus sentidos, se puede ver porqué el símbolo se justifica como camino a seguir para la comprensión del mal. 
tampoco la teodicea de Leibniz (Ibidem, 180) ni la dialéctica de Hegel (Ibidem, 182 - 183) las que colocaron, dentro de sus preocupaciones centrales, el dar consuelo al sufrimiento y el dolor humano.

Como una manera de superar esta deficiencia, propone una importante exigencia: ser responsable ante el mal consiste en no quedarse en la mera especulación, sino en un actuar y un sentir (Ibidem, 185). El hombre debe transformar espiritualmente sus sentimientos, y obrar tanto moral como políticamente respecto al mal (Idem; Ibidem, 186). La acción es necesaria, ya que coloca al hombre de frente al porvenir; ya no es, como en el pensar especulativo, una postura que tiende al pasado — reflejada en la pregunta sobre el origen: ¿de dónde viene el mal? -, sino que ahora la pregunta empuja al futuro: ¿qué hacer contra el mal? El mal, para la acción, es algo que no debería ser, por lo que su tarea es combatirlo: "Esta respuesta práctica tiene efecto en el plano especulativo: antes de acusar a Dios o de especular sobre un origen demoníaco del mal en Dios mismo actuemos ética y políticamente contra el mal" (Ibidem, 187). Ahora bien, en cuanto el sufrimiento infligido por hombres está repartido arbitraria e injustamente, y también en cuanto hay fuentes de sufrimiento diferentes a la acción injusta de unos hombres contra otros — catástrofes naturales, epidemias, etc.-, la acción por sí sola no basta. Frente a la pregunta “¿por qué yo?”, Ricoeur agrega, a la respuesta práctica, una respuesta emocional, que se refiere a las "transformaciones por las cuales los sentimientos que nutren el lamento y la queja pueden pasar bajo los efectos de la sabiduría enriquecida por la meditación filosófica y teológica" (Idem). El objetivo primario de esta respuesta frente al mal, como también lo es de la respuesta práctica, es hacerse cargo del sufrimiento, tarea que llega a constituirse en uno de los desafíos fundamentales planteados por Ricoeur.

Por otro lado, como hacer el mal es hacer sufrir a otro, se está haciendo referencia a aquella idea ricoeuriana de que el mal cometido por un hombre encuentra su réplica en el mal padecido por otro (Ibidem, 173), toda acción, sea ética o política, "que disminuye la cantidad de violencia ejercida por unos hombres contra otros disminuye la tasa de sufrimiento en el mundo" (Ibidem, 186). Luego, actuar contra el mal moral es de vital importancia, en cuanto que, para el filósofo francés, la violencia "no deja de rehacer la unidad entre el mal moral y el sufrimiento"(Idem), es decir, porque am- 
bos tipos de mal se encuentran inevitablemente relacionados: luchar contra el mal moral es luchar contra el sufrimiento (Ibidem, 187'16).

Se puede comprender, de acuerdo a lo planteado por estos autores, que ya no basta con concebir nuevas formas de asumir la responsabilidad personal frente al mal: debe re-pensarse el sentido mismo de la responsabilidad (Bernstein 2004, 325).

\section{Tomás de Aquino y la naturaleza metafísica de su doc- TRINA SOBRE EL MAL}

En el presente apartado se establecerá qué es exactamente lo que entiende por mal santo Tomás de Aquino, tarea que se abordará identificando aquellos principios propios de su metafísica sobre los cuales se construye dicha doctrina.

\section{A) EL MAL EXISTE ${ }^{17}$}

Santo Tomás, en lugares como el Comentario a las Sentencias de Pedro Lombardo y la Suma Teológica, se preocupa de aclarar en qué consiste esta existencia, o, mejor dicho, de qué modo se dice del mal que existe. Para explicarlo, en la primera de estas obras retoma una idea heredada de la Metafísica de Aristóteles (Aristóteles 2011, Libro V, c.7, 1017 a 22-35), que abrazó desde los inicios de su producción filosófica, cuando escribió, allá por 1252 , el Del ente y la esencia ${ }^{18}$ en el artículo 1 de la distinción 34 del Libro II -titulado, precisamente, "si existe el mal"-, santo Tomás afirma que hay dos modos en que se dice el ente:

16 Esto también se puede lograr con la respuesta emocional del duelo, ya que ella permite aprender a aceptar la pérdida del objeto amado, con el fin de no sentirlo como una pérdida de nosotros mismos, lo que nos liberaría para construir nuevos afectos.

17 LUGARES COMUNES: In I Sent., d.46, a.3; In II Sent., d.34, a.1. C. G., III, 71. In De div. nom., 4, lect.16. De Potentia, q.3, a.6, ad 4. Comp. theol., I, 142. S. Th., I, q.22, a.2, ad 2; q.48, a.2.

18 Santo Tomás establece esta idea en las primeras líneas de esta obra: "Hay que saber que, como dice el Filósofo en el libro V de la Metafísica, el ente por sí se dice de dos modos: de un modo por el que se divide en los diez géneros, de otro modo por el que significa la verdad de las proposiciones" ("Sciendum est igitur quod, sicut in V Methaphisice Philosophus dicit, ens per se dupliciter dicitur: uno modo quod dividitur per decem genera, alio modo quod significat propositionum veritatem”). De ente et ess., 1, 1-5. 
... de un modo se dice el ente que se divide en diez géneros, y así el ente significa algo que existe en la naturaleza real, ya sea sustancia, como el hombre, ya sea accidente, como el color. De otro modo se dice el ente que significa la verdad de la proposición, en cuanto se dice que la afirmación es verdadera cuando significa el ser acerca de aquello que es, y la negación, cuando significa el no ser de aquello que no es; y este ente significa la composición que el intelecto encuentra componiendo y dividiendo ${ }^{19}$ (In II Sent., d.34, a.1, c).

A partir de esta cita, se puede afirmar que todo ente que se diga del primer modo puede ser dicho también del segundo, como, por ejemplo, de un hombre, que es una naturaleza real, es decir, se dice de este ente del primer modo, y del que, a su vez, se puede construir una proposición afirmativa, "este hombre es sabio", que es el ente dicho según el segundo modo. Pero esto no se da a la inversa: aquello de lo que se dice que es un ente según el segundo modo no tiene, necesariamente, un ser natural en las cosas (De ente et ess., 1, 5-13 ${ }^{20}$ ).

En el caso del mal, cuando se dice de este que es un ente, que existe, se le está diciendo de solo uno de estos modos. Para explicar a cuál de los dos corresponde, es necesario, primero, comprender en qué consiste verdaderamente el mal.

\section{B) ¿QUÉ ES EL MAL?}

\section{b.1) ¿Es una naturaleza?}

La explicación teórica del modo en que se dice del mal que es un ente, conduce a nuevas preguntas. El aquinate presenta una de las principales inquietudes en la

19 "Uno enim modo dicitur ens quod per decem genera dividitur: et sic ens significat aliquid in natura existens, sive sit substantia, ut homo, sive accidens, ut color. Alio modo dicitur ens, quod significat veritatem propositionis; prout dicitur quod affirmatio est vera, quando significat esse de eo quod est; et negatio, quando significat non esse de eo quod non est; et hoc ens compositionem significat, quam intellectus componens et dividens adinvenit”.

20 Para el aquinate, es diferente la manera en que se predica ente en cada uno de estos modos: se predica de manera esencial según el primero - lo que corresponde a la pregunta quid est (qué es) — y de manera accidental según el segundo, lo que corresponde a la pregunta an est (si es). In II Sent., d.34, a.1, c. 
Prima Pars de la Suma Teológica: "Ser y cosa son convertibles. Luego, si el mal está realmente en las cosas, el mal es alguna cosa" (S. Th., I, q.48, a.2, ob $2^{21}$ ). Lo que en esta cita se plantea es que, si el mal existe, necesariamente tiene que ser una naturaleza real. Esto implica decir del mal que es un ente según el primer modo, ya que, como afirma en el mismo artículo, en este primer modo o sentido ser y cosa se identifican, es decir, son convertibles (Ibidem, ad 2). Pero, evidentemente, esta no es la única opción. Pese a lo que muchos piensan -como lo hace el maniqueísmo-, el mal no es una naturaleza. ${ }^{22}$

Las distintas aproximaciones que el aquinate presenta para demostrar esta idea tienen una base común, aquel principio heredado de la Ética a Nicómaco de Aristóteles (Aristóteles 1994, Libro I, 1094 a 2-3), que enseña que, propiamente hablando, algo es bueno en cuanto es apetecible (De Malo, q.1, a.1, $\mathrm{c}^{23}$ ), o, dicho de otra manera, el bien es lo que todos apetecen (Comp. theol., I, 11524).

Una primera aproximación será tomada del Compendio de Teología, específicamente del capítulo 115 del Libro I; este se inicia afirmando que "toda naturaleza o es un acto o una potencia o un compuesto de ambos" $\left(\operatorname{Idem}^{25}\right)$. Ahora, el acto, en cuanto es perfección (Idem) ${ }^{26}$, tiene razón de bien; la potencia, en cuanto se encuentra naturalmente ordenada al acto -lo apetece, precisamente, en cuanto es un bien-, asimismo tiene bondad; y lo que está compuesto de acto y potencia, en cuanto participa del acto, participa también de la bondad. Se concluye, de esta manera, que toda naturaleza es un bien en sí misma.

21 “... ens et res convertuntur. Si ergo malum est ens in rebus, sequitur quod malum sit res quaedam”. S. Th., I, q.48, a.2, ob 2 .

22 LUGARES COMUNES: In II Sent., d.34, a.2. De ente et ess., 1. C. G., III, 7-9. In De div. nom., 4, lect.14. De Potentia, q.3, a.16, ad 3. Comp. theol., I, 115. S. Th., I, q.48, a.1. De Malo, q.1, a.1.

23 “... bonum proprie est aliquid in quantum est appetibile”.

24 "Bonum vero est quod omnia appetunt".

25 "Nam omnis natura vel est actus vel potentia aut compositum ex utroque".

26 "Cada cosa es perfecta en la medida en que está en acto, porque el acto es la perfección de la cosa” (“... unumquodque secundum hoc completur quod fit in actu, nam actus est perfectio rei"). 
Para una segunda aproximación hay que remitirse al artículo 1 de la cuestión 48 de la Prima Pars:

Un opuesto se conoce a través del otro, como las tinieblas por la luz. Según esto, por el bien se puede conocer el mal. Hemos dicho ${ }^{27}$ que el bien es todo aquello que es apetecible. Ahora bien, como toda naturaleza apetece su ser y su perfección, necesariamente se ha de afirmar que el ser y la perfección de cualquier naturaleza tiene razón de bien (S. Th., I, q.48, a.1, c. ${ }^{28}$ ).

Santo Tomás, en este texto, ensaya el siguiente silogismo: Todo lo apetecible es un bien (Premisa 1); Toda naturaleza apetece su ser y su perfección (Premisa 2); El ser y la perfección de toda naturaleza son un bien (Conclusión). A partir de este raciocinio, y tal como lo hizo en la aproximación anterior, logra establecer la idea de que toda naturaleza es buena (Comp. theol., I, 115 29 ).

Este es, a su vez, el mismo objetivo que tiene la tercera y última aproximación. Revisando nuevamente el capítulo 115 del Compendio de Teología, se puede encontrar la idea de que "toda naturaleza está completa cuando tiene el ser en acto" (Idem $\left.{ }^{30}\right)$. Ahora bien, como el ser es algo apetecido por todos, la completitud de toda naturaleza se logra por la participación del bien (Idem).

27 El aquinate deja establecida esta idea sobre el bien en la misma Prima Pars de la Suma Teológica, específicamente en los artículos 1 y 3 de la cuestión 5, cuando trata sobre el bien en general.

28 “... unum oppositorum cognoscitur per alterum, sicut per lucem tenebra. Unde et quid sit malum, oportet ex ratione boni accipere. Diximus autem supra quod bonum est omne id quod est appetibile: et sic, cum omnis natura appetat suum esse et suam perfectionem, necesse est dicere quod esse et perfectio cuiuscumque naturae rationem habeat bonitatis". S. Th., I, q.48, a.1, c.

29 Siguiendo una estructura similar, esta misma idea ya había sido señalada en el Compendio de Teología: "Toda naturaleza apetece la conservación de su ser y evita su destrucción en cuanto puede. Como aquello que todos apetecen es el bien y aquello de que todos huyen es el mal, es necesario decir que ser una naturaleza es bueno en sí...” “... quelibet natura appetit conservationem sui esse et fugit destructionem quantum potest. Cum igitur bonum sit quod omnia appetunt, malum vero e contrario quod omnia fugiunt, necesse est dicere quod esse unamquamque naturam secundum se sit bonum...").

30 "Omnis autem natura completur per hoc quod habet esse in actu". 
Como se puede apreciar, cada uno de estos tres razonamientos encuentra su cierre en una misma conclusión: toda naturaleza, en sí misma, es un bien. ${ }^{31}$ Se puede enunciar esta misma idea, en su versión negativa: "es imposible que el mal signifique algún ser o alguna forma o naturaleza" (S. Th., I, q.48, a.1, c. ${ }^{32}$ ). Ninguna naturaleza, en sí misma, es un mal.

Es posible responder, a partir de lo expuesto, a la inquietud presentada un poco más atrás: el error de aquellos que sostenían que la existencia del mal implicaba necesariamente que este fuera algo, una cosa o naturaleza, radicaba precisamente en no atender a ese doble modo o sentido en que se puede considerar la palabra ente (Ibidem, a.2, ad 2.). El mal existe, pero no lo hace como una naturaleza, que es lo mismo que decir que es un ente según el segundo modo.

\section{b.2) El mal designa una ausencia o carencia de bien}

Si el mal no es una cosa, ¿cómo puede ser que exista? La idea que en este punto debe ser establecida -habiendo ya determinado que el mal existe (de qué modo se dice que lo hace) y que no es una naturaleza-, a partir de la reflexión precedente, es que el mal designa una ausencia o carencia de bien.

... es necesario que con la palabra mal se designe alguna carencia de bien. Por eso se dice que el mal ni es algo que existe ni bueno; porque, como todo ser, en cuanto tal, es bueno, así la carencia de ser y la carencia de bien son igualmente una misma cosa (Ibidem, a.1, c. ${ }^{33}$ ).

31 Se puede reconocer que, en todos ellos, la vía argumentativa que toma el aquinate es una vía positiva, es decir, un camino en el que se propone determinar lo que sí es una naturaleza —un bien - Es importante señalar que santo Tomás también plantea vías negativas al tema, aquellas que apuntan a determinar lo que no es una naturaleza -precisamente, un mal-. Se aclara que estas no fueron utilizadas aquí porque estos argumentos, para su construcción, requieren haber establecido previamente lo que es el mal, tarea que aún no ha sido abordada en la presente investigación.

32 "Unde non potest esse quod malum significet quoddam esse, aut quandam formam seu naturam".

33 "Relinquitur ergo quod nomine mali significetur quaedam absentia boni. Et pro tanto dicitur quod malum neque est existens nec bonum: quia cum ens, inquantum huiusmodi, sit bonum, eadem est remotio utrorumque". 
Se puede identificar en este texto una de las doctrinas fundamentales de la metafísica tomista: los trascendentales. En ella se plantea una identificación entre bien y ser (De Malo, q.1, a.1, c.), lo que se traduce en que todo ser, en cuanto tal, es bueno. De esta manera, al identificarse el bien con el ser, la pérdida de uno implica la pérdida de otro, por lo que el mal involucra una carencia de ser (In II Sent., d.34, a.2, c. ${ }^{34}$ ). A partir de la idea de que el mal no tiene razón de ser, se deduce que no puede haber entidades en sí mismas malas; lo que hay son naturalezas que se encuentran afectadas por el mal.

\section{b.3) El mal es una oposición al bien}

El mal queda así establecido como una oposición al bien. Cabe preguntarse, ¿qué significa, realmente, ser opuesto al bien? ¿De qué manera se le opone? Es fundamental responder estas interrogantes si lo que se pretende es comprender adecuadamente lo que es el mal.

Una oposición implica la existencia de dos términos, extremos o polos, que se encuentran en una relación recíproca de exclusión. Que estas realidades se opongan mutuamente significa que una de ellas "implica o engloba la negación" (Alvira Clavell - Melendo 2001, 137) de la otra, y viceversa. Ahora bien, no toda oposición manifiesta el mismo grado de negación. Hay distintas formas en las que se puede dar la oposición, dependiendo de la fuerza o intensidad con que se opongan los polos. Siguiendo un orden creciente en cuanto a la intensidad, pueden ser agrupadas en cuatro tipos: la oposición relativa, la contrariedad, la privación y la contradicción. Frente a esta división, heredada de Aristóteles (Aristóteles 2008, c.10, 11 b 17$\left.19^{35}\right)$, lo que incumbe determinar es a cuál de estos tipos de oposición corresponde

34 "Por lo tanto, hay que decir que el mal designa un no ente" ("Dicendum ergo quod malum nominat non ens"). In II Sent., d.34, a.2, c.

35 "Una cosa puede ser opuesta a otra de cuatro maneras diferentes; o como lo son los relativos, o como los contrarios, o como privación y posesión, o, por último, como afirmación y negación. Y para servirnos de ejemplos, todas estas cosas son opuestas entre sí, como en los relativos el doble lo es a la mitad; en los contrarios, el bien lo es al mal; en la privación y posesión, la ceguera a la vista; y, en fin, en la afirmación y negación, estar sentado a no estar sentado". También se puede acudir al capítulo 10 del Libro V de Aristóteles, Metafísica para encontrar otro desarrollo de esta teoría de los opuestos (1018 a 20-1018 b 8). 
el mal. A través de una revisión de la naturaleza de cada uno se podrá lograr mejor este objetivo.

La oposición relativa es la de menor intensidad, en cuanto que cada uno de los términos o extremos no excluye radicalmente al otro. Esta relación de oposición es la que se da, por ejemplo, entre un padre y su hijo, o entre la derecha y la izquierda. Su limitada intensidad se debe a que, si bien aquí los términos efectivamente se excluyen -el padre no es el hijo-, es decir, que no hay identificación posible entre ellos, sin embargo, por su relación, cada uno reclama la existencia del otro (Alvira - Clavell - Melendo 2001, 139): sin hijo, no puede haber padre.

La oposición por contrariedad manifiesta una mayor intensidad que la anterior; es la que media, por ejemplo, entre lo frío y lo caliente, o entre lo masculino y lo femenino. Su mayor intensidad se debe a que aquí no hay reclamación entre los extremos. Tal como en el tipo anterior, estos tampoco se identifican: por ejemplo, el hombre no es mujer, pero, además, el hombre no necesita, como sí lo hacía el padre respecto al hijo, para ser tal, de la presencia de la mujer; los términos, en este sentido, son independientes el uno del otro. Ahora bien, no es una oposición absoluta, ya que los extremos conservan una identidad de género (Idem); en ejemplo utilizado, tanto el hombre como la mujer comparten una perfección común: ambos son seres humanos; estos dos extremos participan de todo lo que implica el hecho de formar parte del género humano, sin que ninguno de los dos elimine "plenamente la perfección que compete a dicha esfera" (Idem).

La tercera forma de oposición es la privación, de mayor intensidad que las dos anteriores, que consiste en la eliminación de "toda la positividad de un determinado dominio ontológico" (Idem). Es la que se da, por ejemplo, entre la audición y la sordera - término con el que se designa, precisamente, la no-audición-. Pese a la profunda negatividad de la privación, tampoco representa una oposición en su grado sumo. Esto se debe a que los términos que la componen "poseen en común un sujeto o soporte entitativo" (Ibidem, 140), es decir, requiere de una realidad, el ser oyente, en la que pueda darse la perfección - la audición - suprimida por dicha privación, la sordera. 
Por último, se encuentra la contradicción, que corresponde al grado mayor de oposición, en cuanto sus elementos se oponen sin que exista comunidad alguna entre ambos -como sí sucedía, de distinta manera, en los otros tipos de oposición-. Es la que se da entre el ente y su negación absoluta, la nada. La contradicción "descarta, en su extremo negativo, cualquier tipo de realidad; $y$, al hacerlo, se manifiesta como oposición acabada y rigurosa" (Idem). De esta manera, este tipo de oposición es el más radical de todos, en cuanto consiste en una pura y simple negación.

Estos son los aspectos diferenciadores de los cuatro tipos de oposición identificados por Aristóteles, los que, cada uno, por separado, y pese a estas diferencias, cumplen con lo que involucra la naturaleza misma de una oposición, la exclusión del término opuesto, constituyendo un todo análogo, con la contradicción como su primer analogado, en cuanto en ella se encuentra de forma plena la cualidad de la oposición (Idem).

Es posible responder ahora a la pregunta sobre el tipo de oposición al que corresponde el mal. No puede consistir, evidentemente, en una oposición relativa, ya que esto implicaría, siguiendo el ejemplo utilizado, que para el padre sería un mal no ser el hijo; tampoco es un mal para el hombre no ser mujer, por lo que no puede consistir en la contrariedad. Entonces, ¿corresponde a la forma de oposición total? El mismo aquinate, en la Suma Teológica, se hace cargo del tema:

... el mal implica carencia de bien (S. Th., I, q.48, a.1, c. ${ }^{36}$ ). Sin embargo, no toda carencia de bien se llama mal. Esta carencia puede ser privativa o meramente negativa. La carencia que es meramente negativa no tiene razón de mal; porque de otro modo habría que decir que las cosas que de ningún modo existen son males, y asimismo que cada cosa sería mala al no tener todo el bien que tienen las demás; sería malo, por ejemplo, el hombre por no tener la agilidad de la cabra ni la fuerza del león (Ibidem, a.3, c. ${ }^{37}$ ).

36 Idea señalada, previamente, en la misma obra: $S$. Th., I, q.48, a.1, c.

37 “... malum importat remotionem boni. Non autem quaelibet remotio boni malum dicitur. Potest enim accipi remotio boni et privative, et negative. Remotio igitur boni negative accepta, mali rationem non habet: alioquin sequeretur quod ea quae nullo modo sunt, mala essent: et iterum quod quaelibet res esset mala, ex hoc quod non habet bonum alterius rei, utpote quod homo esset malus, quia non habet velocitatem capreae, vel fortitudinem leonis". 
En estas palabras se aprecia que, para santo Tomás, el mal no consiste en la pura negación de bien. Se puede imaginar, como ejemplo, a un árbol y a una persona ciega: lo que tienen en común es que ninguno de los dos puede ver. En el caso del árbol, se sabe que no tiene el bien de la vista en cuanto es un ser por naturaleza no-vidente - de partida, no tiene ojos para ver-, lo que significa que es un ser al que no le corresponde poseer dicha perfección; en su caso, esa carencia del bien de la visión es una simple negación. Por eso no se dice del árbol que se encuentra en desgracia por "su ceguera": en el no tener visión del árbol no se da una real pérdida de bien, ya que no se puede perder lo que nunca se ha tenido. Luego, el no poseer la visión no puede ser un mal para este (De Malo, q.1, a.3, c.).

La contradicción, entonces, en cuanto oposición absoluta, es decir, en cuanto consiste en una oposición simplemente negativa, no puede ser un mal.

En el caso del hombre, en cambio, en cuanto su naturaleza propia exige la posesión de la visión, la carencia de dicha perfección sí es un mal para él: aquí efectivamente hay una real pérdida de bien. El aquinate deja en claro que "la carencia de bien que llamamos mal, es la privativa; como el mal de la ceguera consiste en la privación de la vista" (S. Th., I, q.48, a.3, c. ${ }^{38}$ ). El mal, por lo tanto, corresponde al tercer tipo de oposición revisado: es la privación de un bien (De Malo, q.1, a.2, ad 3..$^{39}$ ).

Se puede concluir, a partir de lo anterior, que el mal difiere igualmente tanto del ser como del no ser tomados en absoluto, ya que, precisamente en cuanto es privación, no es ni pura posesión (habitus) ni pura negación (S. Th., I, q.48, a.2, ad 1.).

38 "Sed remotio boni privative accepta, malum dicitur: sicut privatio visus caecitas dicitur".

39 “... el mal es privación...” ("malum autem est privatio”). No es sino esta la razón por la que ubica, en la Suma Teológica, en el marco del tratado sobre la creación, su reflexión sobre el mal inmediatamente a continuación de la distinción en general entre los seres, como la primera distinción en especial: el mal, en cuanto privación, corresponde a la oposición más radical al ser -al bien- una vez que este se halla ya existiendo, es decir, sin contar aquella negación absoluta de la contradicción, que implica un no ser. 


\section{b.4) EI mal es la ausencia de un bien debido (In II Sent., d.34, a.2, c.)}

Santo Tomás, siguiendo una observación propuesta por primera vez por San Anselmo de Canterbury, completa, y mejora, la concepción del mal como mera privatio boni. A partir de la conclusión de que el mal se opone al bien con una oposición privativa, no contradictoriamente, se puede afirmar que el mal no es la ausencia de cualquier bien, sino que corresponde a la ausencia de un bien debido:

Como el mal es privación y no mera negación del bien, según hemos dicho (S. Th., I, q.48, a.3, c.), no toda carencia de bien es un mal, sino que solamente lo es la carencia de un bien que se puede y se debe tener (Ibidem, a.5, ad $1^{40}$ ).

El mal no es solo una privatio boni, como enseñó San Agustín de Hipona en sus Confesione "el mal no es sino la privación del bien" (Agustín De Hipona 1998, III, $7^{41}$ ), sino que es una privatio boni debiti, la privación en una naturaleza de un bien exigido por esta (De Malo, q.1, a.3, c. ${ }^{42}$ ).

\section{c) Definición de mal}

Hasta este punto se ha ido construyendo la noción de mal del aquinate a partir de la identificación de los principales elementos que la componen. Es posible encontrar, de todas maneras, una definición explícita en cada una de las seis obras en las que la cuestión del mal ocupa un lugar relevante entre los temas que en ellas son abordados, a saber, el Comentario a las Sentencias de Pedro Lombardo, la Suma contra gentiles, el Comentario a Sobre los nombres divinos del Pseudo-Dionisio, el Compendio de Teología, la Suma Teológica y las Cuestiones disputadas sobre el mal (Castro

40 “... quia malum privatio est boni, et non negatio pura, ut dictum est supra; non omnis defectus boni est malum, sed defectus boni quod natum est et debet haberi”.

41 “... malum non esse nisi privationem boni...”.

42 Como señala en las Cuestiones disputadas sobre el mal, en cuanto privación, el mal "es la falta de lo que debería estar por naturaleza y no está” (“... est defectus eius quod est natum inesse et non inest”). 
2003, 609-618, 612 3 ). Una completa enunciación de esta se encuentra en el Compendio de Teología: "así como entendemos por bien la perfección del ser, por mal se entiende la privación de esta perfección. Pero, como la privación propiamente dicha es la privación de un bien debido, que le pertenece en un tiempo y de un modo determinado, es evidente que una cosa es llamada mala porque carece de una perfección que debe tener" (Comp. theol., I, 114. ${ }^{44}$ ).

¿Cómo lo define en las obras restantes?: "no toda carencia de bondad es un mal, sino solo la carencia de aquella que la cosa puede tener naturalmente y que le es debida" (In II Sent., d.34, a.4, c c5); “Toda privación, por tanto, tomada propia y estrictamente, lo es de algo que uno tiene y debe tener por naturaleza" (C. G., III, $6^{46}$ ); "el mal es (...) la ausencia de algún bien que debe tener y no tiene" (In De div. nom., 4, lect.14, n. $\left.476^{47}\right)$; "Como el mal es privación (...) no toda carencia de bien es un mal, sino que solamente lo es la carencia de un bien que se puede y se debe tener" (S. Th., I, q.48, a.5, ad $\left.1^{48}\right)$; "el mal no es otra cosa que la privación de la perfección debida (...) porque decimos que una cosa está privada cuando carece de algo que debería tener por naturaleza" (De Malo, q.1, a.2, $\left.\mathrm{c}^{49}\right)$.

Como se puede apreciar en este conjunto de definiciones, la manera en que santo Tomás concibe el mal no varía durante el transcurso de su producción filosófica.

43 Otro autor que también considera que es en estas seis obras que el aquinate desarrolla con mayor profundidad el tema del mal es Sixto J. Castro, específicamente en su introducción a la edición bilingüe que la Biblioteca de Autores Cristianos realizó de la cuestión 1 de las Cuestiones disputadas sobre el mal, publicada el 2003 en la serie "Opúsculos y cuestiones selectas".

44 “... sicut nomine boni intelligitur esse perfectum, ita nomine mali nichil aliud esse intelligitur quam privatio esse perfecti. Quia vero privatio proprie accepta est eius quod natum est et quando natum est et quomodo natum est haberi, manifestum est quod ex hoc aliquid dicitur malum quod caret perfectione quam debet habere”.

45 “... non enim omnis carentia bonitatis malum est, sed illius tantum quam nata est res habere, et debita est ei”.

46 "Omnis autem privatio, si proprie et stricte accipiatur, est eius quod quis natus est habere et debet habere".

47 "mala autem est (...) deficit ab aliquo bono quod debet habere et non habet".

48 “... quia malum privatio est boni (...) non omnis defectus boni est malum, sed defectus boni quod natum est et debet haberi".

49 "malum nihil aliud sit quam privatio debitae perfectionis (...) hoc privari dicimus quod natum est habere aliquid et non habet". 


\section{Tomás de Aquino y la fundamentación CReacionista de SU DOCTRINA SOBRE EL MAL}

Esta metafísica del ser sobre la cual se construye la noción de mal de santo Tomás, puede ser explicada, a su vez, por el fundamento que le entregan ciertos principios que se enmarcan en un ámbito metafísico aún más amplio: el de la Creación.

Dios, creador de todo, es uno y simple: su ser y su esencia se identifican, que es lo mismo que decir que su esencia es ser. No ocurre lo mismo, sin embargo, con su criatura. El individuo creado está compuesto de dos co-principios: el acto de ser y la esencia finita. Se entiende por "acto de ser" la perfección recibida de Dios, mientras que por "esencia finita" al sujeto receptor de dicha perfección (Echavarría 2012, 521544). ¿Por qué es importante esta diferencia entre ser y esencia? Porque solamente teniendo en consideración este principio, que es la razón de la relevancia del sistema metafísico de santo Tomás, puede entenderse verdaderamente la doctrina del mal como "privación": esta diferencia equivale a decir que el sujeto y la perfección que este posee no son idénticos (Cardona 1987, 155), y es precisamente en esta no identidad que radica su natural falibilidad, su apertura a una pérdida de perfección, ${ }^{50} \mathrm{es}$ decir, su apertura al mal. Si hubiese identidad entre el sujeto creado y la perfección recibida, no podría darse esta privación o carencia de perfección debida.

Al respecto, señala en las Cuestiones disputadas sobre el mal:

Mas el bien que es la perfección es privado mediante el mal, por eso en ese bien no puede haber mal. En cambio, el bien que está compuesto de sujeto y de perfección disminuye mediante el mal, por cuanto se quita la perfección y permanece el sujeto. Por ejemplo, la ceguera priva de la vista, disminuye al ojo que ve y está en la sustancia del ojo o incluso en el animal como en el sujeto. Por eso, si hay algún bien que sea acto puro y no tenga ninguna mezcla

50 Como también a una adquisición de perfección. 
de potencia, y así es Dios, en ese bien no puede haber mal de ninguna manera (De Malo, q.1, a.2, c. ${ }^{51}$ ).

Una auténtica privación solo puede darse en un ente que posea potencialidad de decaer en el bien, y, para que ello ocurra, dicho ente no puede ser simple, sino que debe estar metafísicamente compuesto. Es esta composición acto-potencial de ser y esencia la causa de la limitación creatural, la que, como se puede deducir de la lectura de santo Tomás, "es la raíz metafísica de la posibilidad de todos los tipos de mal" (Echavarría 2012, 536).

Ahora bien, pese a que ya ha sido identificada la fuente del mal en las cosas, aun puede hacerse una última pregunta, aquella que aborda el porqué de dicha limitación creatural: ¿qué es lo que explica esta limitación inherente a cada ser creado? Esta idea se fundamenta en la aceptación de una forma específica de creación: es esta una creación ex nihilo, a partir de la nada. Esta expresión no debe entenderse en el sentido de que la nada corresponda al principio material del que Dios hizo el mundo, a la manera de una materia informe a la que dio forma con su acto creador, ya que esto implicaría que dicho material sería preexistente, pero, como señala el aquinate, "nada hay que preexista a la creación" (In II Sent., d.1, q.1, a.2, c. ${ }^{52}$ ). Si lo hubiese sido, tendría que haber correspondido a algo distinto de Dios, o incluso a Dios mismo, lo que no es posible, ya que no puede concebirse una causa distinta e independiente de la Causa Primera, como tampoco, teniendo en consideración los atributos divinos, podría constituirse Él en el principio material de todo lo creado.

Cuando se dice que algo es hecho a partir de la nada, la preposición a partir de no indica causa material, sino tan solo orden; como cuando decimos que el mediodía se hace de la mañana, que no indica más que después de la mañana viene el mediodía. Pero hay que tener presente que la preposición a partir de

51 "Bonum autem quod est perfectio per malum privatur, unde in tali bono non potest esse malum. Bonum autem quod est compositum ex subiecto et perfectione diminuitur per malum, in quantum tollitur perfectio et remanet subiectum, sicut caecitas privat visum et diminuit oculum videntem, et est in substantia oculi vel etiam in ipso animali sicut in subiecto. Unde si aliquod bonum est quod est actus purus nullam potentiae permixtionem habens, cuiusmodi est Deus, in tali bono nullo modo potest esse malum”.

52 "... nihil est quod creationi praeexistat". 
puede incluir negación cuando digo nada, o también puede estar incluida en ella. Si se toma incluyendo la negación, entonces permanece el orden, y se indicará el orden de sucesión entre lo que es y el no ser. En cambio, si la negación incluye la preposición, entonces se niega el orden, y su sentido sería: se hace de la nada, esto es, no está hecho de algo; es como cuando se dice que uno habla de nada porque no habla de algo. Ambos sentidos son aplicables cuando se dice que algo se hace a partir de la nada. En el primer sentido, la preposición a partir de indica orden; en el segundo, implica relación de causa material, la cual es negada (S. Th., I, q.45, a.1, ad 3. ${ }^{53}$ ).

Como aclara este pasaje de la Suma Teológica, ex nihilo se puede entender o bien en un sentido "temporal", en cuanto implica un orden de sucesión, un "antes hubo nada y después hubo algo", o bien como una negación de cualquier causalidad material en el acto creador de Dios, la idea de que las criaturas "no fueron hechas a partir de algo". ${ }^{54}$

La creación ex nihilo, por consiguiente, significa que Dios, radicalmente, a partir de la inexistencia total, del no ser absoluto, les ha dado el ser a todas las cosas; y es precisamente este el aspecto a considerar: las criaturas, si bien tienen el ser en acto, no lo poseen de manera perfecta, porque llegaron a tenerlo después de no haberlo tenido. Si bien ahora son, hubo un antes en que no fueron. Luego, su acto de ser no les es propio, sino algo extrínseco, que recibieron de la causalidad eficiente de su Creador; es un ser que no les pertenece, que lo tienen "prestado". Esto explica el que no sean inseparables de dicho acto de ser, y que, por este motivo, puedan llegar a perderlo, a dejar de ser en acto.

53 “... cum dicitur aliquid ex nihilo fieri, haec praepositio ex non designat causam materialem, sed ordinem tantum; sicut cum dicitur, ex mane fit meridies, idest, post mane fit meridies. Sed intelligendum est quod haec praepositio ex potest includere negationem importatam in hoc quod dico nihil, vel includi ab ea. Si primo modo, tunc ordo remanet affirmatus, et ostenditur ordo eius, quod est ad non esse praecedens. Si vero negatio includat praepositionem, tunc ordo negatur, et est sensus, fit ex nihilo, idest non fit ex aliquo; sicut si dicatur, iste loquitur de nihilo, quia non loquitur de aliquo. Et utroque modo verificatur, cum dicitur ex nihilo aliquid fieri. Sed primo modo, haec praepositio ex importat ordinem, ut dictum est: secundo modo, importat habitudinem causae materialis, quae negatur".

54 Esto es lo que distingue al acto creador de Dios con cualquier acto productivo del hombre: este último siempre necesita de un sustrato al cual darle forma. 
Dios, que es eterno, subsistente y necesario - el ipsum esse subsistens - tiene el ser por esencia, lo que significa que lo posee de un modo completo, ilimitado, mientras que las finitas y contingentes criaturas, en cuanto alguna vez no fueron, es decir, en cuanto han venido al acto después de haber sido en potencia, no son esencialmente existentes — poseen parcialmente dicho acto de ser, de una manera no plena- El ser creado, siguiendo aquí otra de las concepciones metafísicas fundamentales del aquinate, solo participa del ser de Dios (Ibidem, a.5, ad 1.,) y es esta participación la que necesariamente implica la composición acto-potencial de ser y esencia. De esta manera, mientras que Dios es la bondad pura y absoluta en cuanto es Acto Puro, lo que implica que no tiene mezcla alguna de potencia en Él, la criatura, por el contrario, es un bien particular porque en su naturaleza se encuentra esa mezcla de potencia, potencialidad que, como señala el aquinate en las Cuestiones disputadas sobre la verdad, se debe a este provenir de la nada, por lo que, finalmente, es esto lo que explica el natural decaimiento del hombre hacia dicha nada, esa tendencia al no $\operatorname{ser}$ (De Veritate, q.24, a.7, c.).

A partir de esto, se puede entender que, en último término, es esta visión creacionista la que explica la presencia del mal en los entes finitos.

\section{La metafísica Creacionista de SANTo Tomás y el Proble- MA DE LA RESPONSABILIDAD}

Esta doctrina del mal que, como quedó desarrollado en los apartados anteriores, se encuentra sostenida por una metafísica creacionista, ¿cómo podría posibilitar una aproximación a un problema fundamentalmente moral como lo es el de la responsabilidad humana ante el mal? Una respuesta a esta inquietud podría comenzar a construirse desde un elemento filosófico en específico, que santo Tomás ubica en las Cuestiones disputadas sobre el mal, en el contexto de su indagación sobre el origen del mal moral de culpa.

Se iniciará esta explicación citando unas palabras de la Suma Teológica que sintetizan la postura fundamental del aquinate sobre el tema, pero que, a su vez, pueden 
provocar confusión respecto a su verdadero alcance: "tanto el ángel como cualquier otra criatura racional, si solo se considera su naturaleza, puede pecar" (S. Th., I, q.63, a.1, c. ${ }^{55}$ ). A partir de esta idea se suele concluir, erróneamente, que la libertad, en cuanto tal, es decir, en cuanto libre, es de por sí malvada. El problema es que afirmar esto implicaría, inevitablemente, el hacer a Dios, en cuanto creador de dicha facultad en las criaturas racionales, causa del mal de culpa por esta producido.

Para enfrentar este problema es necesario hacer una importante aclaración. En las Cuestiones disputadas sobre el mal presenta la idea de que el bien puede ser causa del mal de dos modos, en cuanto es agente indirectamente y en cuanto es un bien deficiente (De Malo, q.1, a.3, c.). El punto es que esta distinción se aplica también a la voluntad: es causa agente indirecta "en cuanto es arrastrada a algo que es bueno en algún sentido, pero tiene unido algo que es de por sí malo" (Idem $\left.{ }^{56}\right)$; y en cuanto bien deficiente "porque hay que considerar previamente en la voluntad algún defecto anterior a la elección deficiente con la que elige algo bueno bajo algún aspecto pero malo de por sí" (Idem $\left.{ }^{57}\right)$. Este segundo modo presenta un aspecto de suma importancia. Plantea que el origen de la culpa en el hombre no se encuentra en una privación, sino, primigeniamente, en una negación (De Malo, q.1, a.3, c. ${ }^{58}$ ), que consiste en un no atender a la regla, en olvidarse de ella:

... en todas las cosas en las que una debe ser regla y medida de la otra, el bien en lo regulado y medido procede de que se ajusta y conforma con la regla y medida, mientras que el mal viene de no regularse y ajustarse. Luego, si un artífice que debiera cortar una madera rectamente de acuerdo con una regla, no lo hiciera correctamente, lo que sería cortar mal, este mal corte estaría causado por este defecto, que el artífice procedió sin regla ni medida. De modo

55 “... tam angelus quam quaecumque creatura rationalis, si in sua sola natura consideretur, potest peccare”.

56 “... in quantum voluntas fertur in aliquid quod est bonum secundum quid, sed habet coniunctum quod est simpliciter malum”.

57 “... in quantum oportet in voluntate praeconsiderare aliquem defectum ante ipsam electionem deficientem, per quam eligit secundum quid bonum quod est simpliciter malum”.

58 Por ello, en este punto, el aquinate recuerda aquellas palabras de San Agustín, quien compara este defecto de la voluntad, en cuanto es simplemente una negación, con el silencio y las tinieblas. La ciudad de Dios, XII, 7. Citado en De Malo, q.1, a.3, c. 
semejante la delectación y todo lo demás en las cosas humanas debe medirse y regularse según la regla de la razón y de la ley divina; luego hay que presuponer en la voluntad el no emplear la regla de la razón y de la ley divina antes de una elección desordenada $\left(\operatorname{Idem}^{59}\right)$.

Si bien el mal de culpa radica en la libre elección desordenada de la voluntad humana, este encuentra su primer momento, su origen, en ese no considerar aquella regla de la que depende la rectitud de la acción elegida y realizada. Ahora, por el hecho de tener que adecuarse a una norma de acción distinta de sí misma, esta no consideración de la regla o medida de sus actos cae bajo la total y exclusiva potestad de la libertad creada (Echavarría 2012, 543). Para santo Tomás, entonces, no hay otra causa que la misma libertad de la voluntad, por la cual puede hacer y no hacer, de este defecto consistente en el no uso de la regla de la razón y de la ley divina (De Malo, q.1, a.3, c.).

Otro punto clave de este argumento se encuentra en que este no atender en acto a dicha regla, ese momento en que, previo a la acción, deja sin consideración aquella medida que debería regir dicho movimiento, no es en sí un mal, "porque el alma no está obligada ni puede atender a esa regla siempre en acto" (Idem). Recién hay culpa de la voluntad cuando, pese al hecho de no tenerla en cuenta, de todas maneras libremente elige actuar. El mal se da cuando tiene lugar la privación, no la negación que la precede (Idem).

De estas dos ideas, a saber, que la no consideración de la regla es una simple negación que se encuentra bajo exclusiva potestad de la libertad finita de la criatura; y que, en sí misma, esta negación no implica un mal, se puede deducir que la libertad creada, en cuanto libertad, no se encuentra constitutivamente dirigida a realizar el mal. ¿Por qué? Porque el defecto de esta no consideración es, precisamente, anterior a la libre elección de actuar sin ella, que es lo que sí constituye un mal.

59 “... in omnibus enim quorum unum debet esse regula et mensura alterius, bonum in regulato et mensurato est ex hoc quod regulatur et conformatur regulae et mensurae, malum vero ex hoc quod est non regulari vel mensurari. Si ergo sit aliquis artifex qui debeat aliquod lignum recte incidere secundum aliquam regulam, si non directe incidat, quod est male incidere, haec mala incisio causabitur ex hoc defectu quod artifex erat sine regula et mensura. Similiter delectatio et quodlibet aliud in rebus humanis est mensurandum et regulandum secundum regulam rationis et legis divinae; unde non uti regula rationis et legis divinae praeintelligitur in voluntate ante inordinatam electionem". 
Es posible encontrar unas palabras referidas a este problema en las Cuestiones disputadas sobre la verdad: "el poder elegir el mal no pertenece a la razón del libre albedrío, sino que se sigue del libre albedrío en cuanto existe en una naturaleza creada que puede decaer" (De Veritate, q.24, a.3, ad $2^{60}$ ). Como quedó establecido en el apartado anterior, esta tendencia a la negatividad, al no ser, esta posibilidad de decaer se da en la "libertad creada" no en cuanto "libertad", sino en cuanto ha sido "creada", es decir, en cuanto ha venido al ser ex nihilo, a partir de la nada (De Veritate, q.22, a.6, ad 3. ${ }^{61}$ ). Como afirma santo Tomás, si bien se espera que la libertad creada peque, Jacques Maritain, siguiendo al aquinate, afirma que "una criatura libre naturalmente no pecable es un círculo cuadrado" (Maritain 1946,201-224, 208), esto no ocurre por el hecho de ser libertad - Dios es absolutamente libre y no peca (C. G., III, 10962) - sino por el hecho de ser una libertad creada. Luego, la libertad falible de la criatura, si bien se encuentra marcada por esta posibilidad de hacer el mal, no está predeterminada a hacerlo por el hecho mismo de ser libertad.

De esto se desprende que no es otra que la misma libertad creada la que, por sí sola, introduce el defecto en su actuar (De Malo, q.3, a.2, c. ${ }^{63}$ ). Es ella la que tiene "la primera iniciativa de la acción inmoral, por detener el curso de la moción divina hacia el bien" (Cruz Cruz 2008, 19-28, p24) ${ }^{64}$, la que, en cierto sentido, tiene la capacidad "de frustrar la voluntad (antecedente) de Dios" (Idem). La criatura libre se constituye, por consiguiente, en la única causa del mal moral de culpa. En la línea del mal, incluso debe considerársele como causa primera de toda privación en su actuar deliberado (S. Th., I-II, q.112, a.3, ad 2).

60 “... posee eligere malum non est de ratione liberi arbitrii sed consequitur liberum arbitrium secundum quod est in natura creata possibili ad defectum”. También en In II Sent., d.44, q.1, a.1, ad 1.

61 “... el hecho de que la voluntad sea flexible hacia el mal no le corresponde en cuanto procede de Dios, sino según que es de la nada" ("... hoc quod voluntas sit flexibilis ad malum non habet secundum quod est a Deo sed secundum quod est de nihilo”).

62 "En Dios, pues, no puede haber pecado de voluntad" ("In Deo igitur peccatum voluntatis esse non potest").

63 Un lugar donde presenta esta idea es la cuestión 3 de las Cuestiones disputadas sobre el mal -que trata sobre las distintas causas del pecado-. En el corpus del artículo segundo, donde se pregunta si la acción de pecado procede de Dios, establece que, en la "acción de pecado", lo que en ella hay de "acción" procede de Dios, en cuanto primer motor que causa la moción de todas las causas segundas, pero lo que en ella hay "de pecado" no debe su causa a Él: "lo que hay ahí de desorden o deformación, no tiene a Dios por causa, sino solo al libre albedrío" ("... quod autem est ibi de inordinatione vel deformitate non habet Deum causam set solum liberum arbitrium”).

64 También en “Tomás de Aquino y el problema del mal: la vigencia de una perspectiva metafísica”, p.543. 
... la libertad creada no tiene necesidad de que Dios concurra con su causalidad para tal "no consideración", porque ella no es propiamente un acto, es decir, algo positivo, sino una pura "negación”, introducida solo por la criatura en su elección (Echavarría 2012, 543)

Como consecuencia especulativa directa de esta idea, se puede entender cómo yerra la criatura racional cuando señala inquisitivamente a su Creador cada vez que se ve expuesto al daño del mal moral de culpa. No se puede acusar a Dios, porque Él no es causa, ni siquiera indirectamente, de esta clase de mal (S. Th., I-II, q.79, a.1, c.). Es más, en cuanto es algo contrario a la intención divina original, nunca debió haber acaecido.

Siguiendo la rotunda doctrina de santo Tomás al respecto, se puede afirmar, en relación a las distintas formas de mal, que Dios es causa indirecta del mal físico, así como también es causa del mal de pena, pero en absoluto lo es del mal de culpa (Ibidem, I, q.49, a.2, c. ${ }^{65}$ )

... no obstante que Dios quiere algunos bienes más que otros, no hay bien que más quiera que su bondad, por lo cual de ninguna manera quiere el mal de culpa, que priva del orden al bien divino. En cuanto al mal de defecto natural $\mathrm{y}$ al mal de pena, los quiere al querer cualquiera de los bienes a que van anejos, y así, al querer la justicia, quiere el castigo, y al querer que se conserve el orden de la naturaleza, quiere que se corrompan algunas cosas (Ibidem, q.19, a.9, c. $\left.{ }^{66}\right)$.

Dios puede querer, indirectamente, el mal físico y el mal de pena, ya que estos entrañan la preferencia de un bien creado sobre otro bien creado, o del bien divino sobre el creado, respectivamente. En el mal de culpa, en cambio, lo que se está prefiriendo es

65 También en Ibidem, q.48, a.6.

66 "Nullum autem bonum Deus magis vult quam suam bonitatem: vult tamen aliquod bonum magis quam aliud quoddam bonum. Unde malum culpae, quod privat ordinem ad bonum divinum, Deus nullo modo vult. Sed malum naturalis defectus, vel malum poenae vult, volendo aliquod bonum, cui coniungitur tale malum: sicut, volendo iustitiam, vult poenam; et volendo ordinem naturae servari, vult quaedam naturaliter corrumpi". 
un bien creado por sobre la bondad infinita de Dios. Dicho de otro modo, la culpa, en cuanto constituye la forma absoluta de mal, se opone radicalmente al Bien absoluto (Echavarría 2012, 543). Es por ello que Él no quiere, de ninguna manera, el mal de culpa, sino que solo lo permite (De Malo, q.1, a.5, c. ${ }^{67}$ ).

\section{Conclusión}

Se pudo constatar que, en santo Tomás, la cuestión del mal encuentra su fundamento en la esfera metafísica, y en una metafísica creacionista. Hablar de mal es hablar de ser, por lo que solo entendiéndolo como un asunto de esta índole se puede llegar a comprender su verdadera naturaleza. Ahora bien, se constató también que dicho fundamento no puede ser considerado una limitante para el efectivo desarrollo de los aspectos antropológicos y morales del pensamiento tomista sobre el mal. Al contrario, es esta misma metafísica la que permite explicar y sustentar la tesis de la absoluta responsabilidad del hombre por aquel mal cometido al hacer uso (abuso) de su voluntad libre. Es en este origen ex nihilo donde radica esa posibilidad cierta $-\mathrm{y}$, lamentablemente, bastante usual - de cometer el mal; pero es precisamente eso, solo una posibilidad: si el mal moral de culpa llega a ser, esto se debe únicamente a la causalidad humana.

Luego, no hay hado o destino, azar o predeterminación, ni entidad absolutamente maligna a quien culpar por la presencia del mal moral de culpa. No es sino la libertad creada la que le ha abierto la puerta para su entrada en el mundo.

Este profundo sentido de responsabilidad humana encuentra su correlato en la absoluta inocencia de Dios frente a dicha forma de mal. Siguiendo la terminología de Maritain (Echavarría 2012, 223), en la línea del bien — o del ser- es Dios la causa

67 "Dios es promotor de la pena, pero no puede ser promotor de la culpa" ("Deus igitur est actor poenae, sed actor culpae esse non potest”). De Malo, q.1, a.5, c. También en el Comentario a las Sentencias de Pedro Lombardo: "Por eso hay que decir que las penas proceden de Dios, pero que de ningún modo proceden de Dios las culpas, aunque unas y otras se llamen males" ("Et ideo dicendum est poenas a Deo esse, nullo autem modo culpam a Deo esse, quamvis utrumque malum dicatur”). In II Sent., d.37, q.3, a.1, c. Esto se manifiesta con claridad en las Sagradas Escrituras: "No eres un Dios que ame el mal, ni es tu huésped el malvado" (Sal 5:5); "Dios aborrece igualmente al impío y su impiedad” (Sb 14:9). 
primera de todo lo existente; pero no sucede lo mismo en la línea del mal, aquella en la que, en cuanto implica no ser, se ubica la privación de la voluntad libre.

Esta visión de la responsabilidad permite una aproximación a la problemática que inquietó a todos aquellos que, como Jonas, vieron afectadas sus creencias ante los hechos acontecidos. Este autor solucionó el dilema de la responsabilidad de Dios por aquel mal radical que Arendt vio surgir en lugares como Auschwitz, a través de un cuestionamiento de sus atributos, específicamente, de su absoluto poder. En el sistema filosófico del aquinate, esto no es necesario: la absoluta responsabilidad del hombre, tal como allí se encuentra fundamentada, no exige la negación de la omnipotencia de Dios. El despliegue de la libertad humana no necesita de este retraimiento, de esta contracción divina. No es sino la categórica exclusión de Dios de la línea del mal lo que permite comprender la total ausencia de responsabilidad que hay en Él.

Asimismo, permite pensar acerca de ese exigente sentido de responsabilidad por el otro tan reclamado en la reflexión contemporánea sobre el mal por autores como Jaspers, Levinas, Jonas y Ricoeur. Si se tiene en consideración, siguiendo al filósofo francés, que es el mismo hombre la principal causa de sufrimiento humano, se puede comprender cómo la filosofía del aquinate, que señala esta responsabilidad total que le compete al género humano por la presencia del mal de culpa en el mundo, podría promover una reflexión sobre el papel que le cabe desempeñar a cada criatura racional en aquello que se constituye en la respuesta ética, para Levinas, o práctica, para Ricoeur, ante el mal, es decir, en ese esfuerzo por disminuir el sufrimiento del otro.

Por consiguiente, es la relación causal entre la voluntad libre y el mal moral de culpa, que determina esta absoluta responsabilidad humana ante dicha forma de mal, aquel elemento propiamente filosófico sobre el cual se puede sustentar un posible aporte del pensamiento del aquinate a la discusión contemporánea sobre esta cuestión. 


\section{Bibliogr AFía}

\section{Bibliografía primaria}

Obras de Santo Tomás de Aquino:

Sancti Thomae de Aquino. 1882-2014. Opera Omnia, Iussu Leonis XIII P.M. Edita. Roma: (edición "Leonina").

1950. In Librum Beati Dionysii De Divinis Nominibus Expositio. Taurini-Romae: Marietti Editori Ltd.

1929-1947. Scriptum super libros Sententiarum magistri Petri Lombardi episcopi Parisiensis. Paris: Sumptibus P. Lethielleux, Editoris:

Tomus I, 1929.

Tomus II, 1929.

Obras de Santo Tomás de Aquino: ediciones en español:

Comentario a las Sentencias de Pedro Lombardo. Pamplona: Ediciones Universidad de Navarra:

Volumen I/2, edición de Juan Cruz Cruz, 2004.

Volumen II/1, edición de Juan Cruz Cruz, 2005.

Volumen II/2, edición de Juan Cruz Cruz, 2008.

1980. Compendio de Teología. Madrid: Ediciones Rialp.

2015. Cuestiones disputadas sobre el mal. Pamplona: Ediciones Universidad de Navarra.

2016. Cuestiones disputadas sobre la verdad, Tomos I-II. Pamplona: Ediciones Universidad de Navarra.

2001. El ser y la esencia, Opúsculos y cuestiones selectas, Tomo I. Madrid: Biblioteca de Autores Cristianos.

2007. Suma contra gentiles, Tomos I-II. Madrid: Biblioteca de Autores Cristianos. Suma Teológica. Madrid: Biblioteca de Autores Cristianos: 
Tomo I, $3^{\text {a }}$ edición, 1964/2a edición, 1994.

Tomo II, 1948/2001.

\section{Bibliografía secundaria}

Alvira, Tomás - Clavell, Luis - Melendo, Tomás. 2001. Metafísica. Pamplona: Ediciones Universidad de Navarra.

Arendt, Hannah. 2006. Los orígenes del totalitarismo. Madrid: Alianza Editorial.

Arendt, Hannah. 2014. Sobre la violencia. Madrid: Alianza Editorial.

Aristóteles. 2008. Categorías, Tratados de Lógica (El Organón). México D.F.:

Editorial Porrúa.

Aristóteles. 1994. Ética a Nicómaco. Madrid: Centro de Estudios Constitucionales.

Aristóteles. 2011. Metafísica. Madrid: Editorial Gredos.

Bernstein, Richard. 2004. El mal radical: una indagación filosófica. Buenos Aires: Ediciones Lilmod.

Bernstein, Richard. 2015. Violencia. Pensar sin barandillas. Barcelona: Editorial Gedisa.

Cardona, Carlos. 1987. Metafísica del bien y del mal. Pamplona: Ediciones Universidad de Navarra.

Castro, Sixto. 2003. “Introducción a la Cuestión sobre el mal”, en De Aquino, Tomás, Cuestión sobre el mal, Opúsculos y cuestiones selectas, Tomo II. Madrid: Biblioteca de Autores Cristianos.

Castro, Sixto. 2016. "Tomás de Aquino y la cuestión del mal. Una lectura contemporánea", Estudios Filosóficos. Salamanca: Editorial San Esteban, mayo-agosto, Volumen LXV, N¹89, 237-253.

Cruz Cruz, Juan. 2008. "El bien y el mal en el orden ontológico de los opuestos", Presentación al Volumen II/2 del Comentario a las Sentencias de Pedro Lombardo, en De Aquino, Tomás, Comentario a las Sentencias de Pedro Lombardo. Pamplona: Ediciones Universidad de Navarra.

De Hipona, Agustín. 1998. Las Confesiones, Obras de San Agustín, Tomo II. Madrid: Biblioteca de Autores Cristianos.

Delbanco, Andrew. 1997. La muerte de Satán. Santiago: Editorial Andrés Bello.

Dosse, François. 2013. Paul Ricoeur: los sentidos de una vida (1913-2005). Buenos Aires: Fondo de Cultura Económica. 
Echavarría, Agustín. 2012. "Tomás de Aquino y el problema del mal: la vigencia de una perspectiva metafísica", Anuario Filosófico, Revista cuatrimestral del Departamento de Filosofía, Facultad de Filosofía y Letras. Pamplona: Universidad de Navarra. Volumen 45, Número 3, 521-544.

Haag, Herbert. 1981. El problema del mal. Barcelona: Editorial Herder.

Jaspers, Karl. 1998. El problema de la culpa. Sobre la responsabilidad política de Alemania. Barcelona: Ediciones Paidós, Ibérica.

Jonas, Hans. 1998. “El concepto de Dios después de Auschwitz. Una voz judía”, Pensar sobre Dios y otros ensayos. Barcelona: Editorial Herder.

Jonas, Hans. 2008. El principio de responsabilidad. Ensayo de una ética para la civilización tecnológica. Barcelona: Editorial Herder.

Levinas, Emmanuel. 1993. "El sufrimiento inútil”, Entre nosotros. Ensayos para pensar en otro. Valencia: Editorial Pre-textos.

Maritain, Jacques. 1946. "Santo Tomás de Aquino y el problema del mal”, De Bergson a Sto. Tomás de Aquino. Buenos Aires: Club de Lectores.

Neiman, Susan. 2012. El mal en el pensamiento moderno. Una historia no convencional de la filosofía. México D.F.: Fondo de Cultura Económica.

Possenti, Vittorio. 1997. Dios y el mal. Madrid: Ediciones Rialp.

Ricoeur, Paul. 2008. "El mal. Un desafío a la filosofía y a la teología", Fe y filosofía: problemas del lenguaje filosófico. Buenos Aires: Prometeo Libros.

Ricoeur, Paul. 2004. Freud: una interpretación de la cultura. México D.F: Siglo XXI Editores. 